\title{
5-Keto-D-fructose production from sugar alcohol by isolated wild strain Gluconobacter frateurii CHM 43
}

Osao Adachi, Thuy M. Nguyen, Roque A. Hours, Naoya Kataoka, Kazunobu Matsushita, Yoshihiko Akakabe \& Toshiharu Yakushi

To cite this article: Osao Adachi , Thuy M. Nguyen, Roque A. Hours, Naoya Kataoka, Kazunobu Matsushita , Yoshihiko Akakabe \& Toshiharu Yakushi (2020): 5-Keto-D-fructose production from sugar alcohol by isolated wild strain Gluconobacter frateurii CHM 43, Bioscience, Biotechnology, and Biochemistry, DOI: 10.1080/09168451.2020.1767500

To link to this article: https://doi.org/10.1080/09168451.2020.1767500

\section{Published online: 19 May 2020.}

Submit your article to this journal $\asymp$

View related articles

View Crossmark data $\nearrow$ 


\title{
5-Keto-D-fructose production from sugar alcohol by isolated wild strain Gluconobacter frateurii CHM 43
}

\author{
Osao Adachia, Thuy M. Nguyen ${ }^{\mathrm{a}}$, Roque A. Hours ${ }^{\mathrm{b}}$, Naoya Kataoka ${ }^{\mathrm{a}}$, Kazunobu Matsushitaa \\ Yoshihiko Akakabe ${ }^{a}$ and Toshiharu Yakushi ${ }^{\mathrm{a}}$
}

${ }^{a}$ Department of Biological Chemistry, Faculty of Agriculture, Yamaguchi University, Yamaguchi, Japan; ${ }^{b} \mathrm{CINDEFI,} \mathrm{School} \mathrm{of} \mathrm{Science,} \mathrm{La}$ Plata National University, La Plata, Argentina

ABSTRACT

Gluconobacter frateurii CHM 43 have D-mannitol dehydrogenase (quinoprotein glycerol dehydrogenase) and flavoprotein D-fructose dehydrogenase in the membranes. When the two enzymes are functional, D-mannitol is converted to 5-keto-D-fructose with $65 \%$ yield when cultivated on D-mannitol. 5-Keto-D-fructose production with almost $100 \%$ yield was realized with the resting cells. The method proposed here should give a smart strategy for 5-keto-D-fructose production.
ARTICLE HISTORY

Received 2 April 2020

Accepted 7 May 2020

KEYWORDS

Acetic acid bacteria;

Gluconobacter frateurii;

5-keto-D-fructose; oxidative

fermentation
Regarding to 5-keto-D-fructose (5KF) production by acetic acid bacteria, the first report was done in 1960 by Terada et al. [1-4]. They identified the unknown substance from $\mathrm{D}$-fructose oxidation to be $5 \mathrm{KF}$. Formation and utilization of $5 \mathrm{KF}$ were reported with Gluconobacter cerinus IFO 3267 [5]. Thereafter, a membrane-bound $\mathrm{D}$-fructose dehydrogenase $(\mathrm{FDH}$, EC 1.1.99.11) catalyzing 5KF formation from $\mathrm{D}$-fructose was purified and characterized as a flavoprotein dehydrogenase-cytochrome complex from the membrane fraction of Gluconobacter industrius IFO 3260 (renamed as Gluconobacter japonicus NBRC 3260) [6]. Later, the genes encoding FDH of NBRC 3260 was identified as $f d h S C L$ and its high expression strain was also constructed [7]. Since the first description of $5 \mathrm{KF}$ production by acetic acid bacteria, many efforts have been done to create a strain for better $5 \mathrm{KF}$ production [8-11]. $5 \mathrm{KF}$ has been evaluated as a natural sweetener with low calorie $[1,12,13]$ that can be substituted with $\mathrm{D}$-glucose preventing metabolic diseases caused by high blood glucose level. Deppenmiere's group reported $5 \mathrm{KF}$ production from D-fructose with genetically modified Gluconobacter oxydans strains where they used plasmid-based $f d h$ of G. japonicus NBRC 3260 [8] or G. japonicus LMG 1281 [9]. Later, Battling et al. [11] reported 5KF production from D-fructose with a novel plasmid-free strain of G. oxydans. The two groups of German scientists elaborated bacterial strains for $5 \mathrm{KF}$ production but the principle has remained within the same scope of Terada et al. [1-4] who used D-fructose as the starting material for $5 \mathrm{KF}$ formation. Deppenmiere's group also reported $5 \mathrm{KF}$ production from sucrose, instead of
D-fructose, with G. oxydans strain having chromosome-integrated $f d h$ of G. japonicas NBRC 3260 and invertase gene of G. japonicus LMG 1417 [10]. In this case, sucrose was efficiently converted to $\mathrm{D}$-fructose and $\mathrm{D}$-glucose, then the $\mathrm{D}$-fructose to $5 \mathrm{KF}$ efficiently, but the $\mathrm{D}$-glucose remained in the culture medium.

We tried to look for alternative convenient substrates for $5 \mathrm{KF}$ production as well as a better $5 \mathrm{KF}$ producing strain among isolated wild strains. D-Mannitol was chosen as the most promising substrates. The reason came from the metabolic characteristics of acetic acid bacteria. In general cases of the oxidative fermentation catalyzed by the cytoplasmic system of acetic acid bacteria, $\mathrm{D}$-sorbitol is oxidized predominantly to L-sorbose and $\mathrm{D}$-mannitol to D-fructose. Crude membrane fraction of Gluconobacter frateurii CHM 43 showed a strong FDH activity (0.8-1.0 unit/mg protein) comparable to that of G. japonicus NBRC 3260 (0.7-1.0 unit/mg) [6]. When G. frateurii CHM 43 was grown in D-mannitol medium, D-mannitol initially added was consumed, then D-fructose accumulation started within 3 days. Thereafter, $5 \mathrm{KF}$ accumulation came to the maximum level while D-fructose disappeared rapidly (Figure 1(a)). The $\mathrm{pH}$ of the culture medium gradually decreased to 4.0. The bacterial growth showed a biphasic (Figure 1(a)). The first phase was brought by D-mannitol oxidation and the second by D-fructose oxidation. In Figure 1(b), an aliquot of the culture supernatant along the cultivation was spotted on a TLC sheet. After it was developed and dried well, the TLC sheet was sprayed by an alkalinetriphenyl tetrazolium chloride (TTC) solution. D-Fructose and 5KF reacted with TTC but not D-mannitol. Since one ketone moiety is found in the

CONTACT Osao Adachi osao@yamaguchi-u.ac.jp

This paper is dedicated to $50^{\text {th }}$ Anniversary of the Laboratory of Applied Microbiology, Yamaguchi University, founded in 1969 by the late Professor Emeritus Minoru Ameyama for studying the oxidative fermentation and biotechnological applications of acetic acid bacteria.

(c) 2020 Japan Society for Bioscience, Biotechnology, and Agrochemistry 

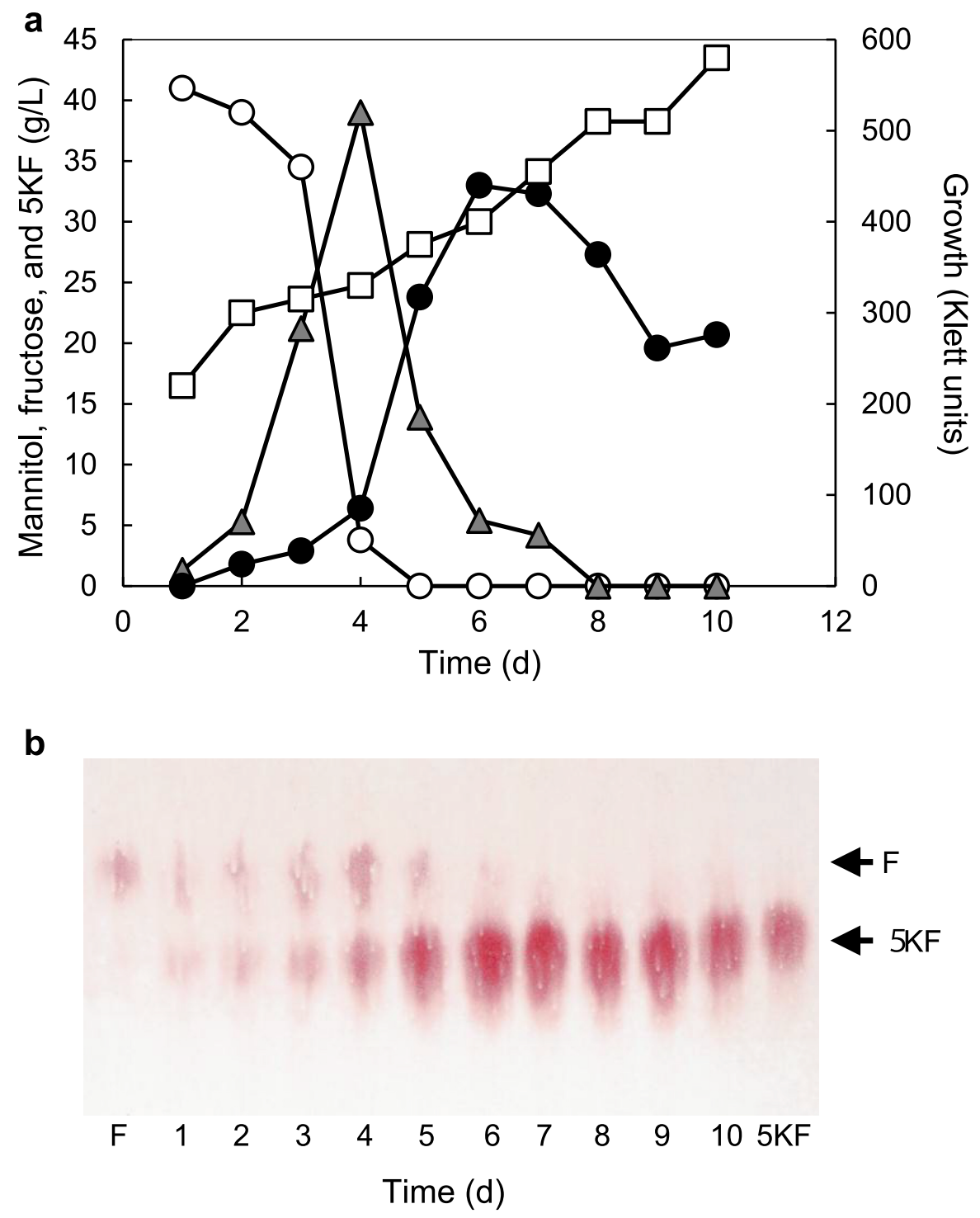

Figure 1. Production of 5-keto-D-fructose during cultivation of G. frateurii CHM 43. (a) The organism was cultured on a medium containing 5\% D-mannitol, $0.3 \%$ yeast extract (Oriental Yeast Co., Ltd, Tokyo), and $0.3 \%$ highpolypepton. The medium (150 mL) was put in an Erlenmeyer flask of $500 \mathrm{~mL}$ volume with a sided arm. The cultivation was done at $30^{\circ} \mathrm{C}$ under shaking at $200 \mathrm{rpm}$. The bacterial growth $(\square)$ was recorded by a Klett Summerson colorimeter through the side arm without taking the cotton stopper off. Incubation was carried out for the period as indicated. D-Mannitol (O) was measured by reading increase of optical density at $340 \mathrm{~nm}$ caused by NADPH when assayed with NADP-MLDH. D-Fructose $(\mathbf{\Delta})$ was measured by two ways [1]: with FDH using potassium ferricyanide as electron acceptor and [2], reduction of D-fructose to D-mannitol by reading decrease of optical density of NADPH at $340 \mathrm{~nm}$. 5KF (•) was measured by reading decrease of optical density of NADPH at $340 \mathrm{~nm}$. The amounts of D-mannitol (O), D-fructose $(\boldsymbol{\Delta})$, and $5 \mathrm{KF}(\bullet)$ in the culture medium were measured as described in the text. (b) An aliquot of the culture medium was spotted on a thin-layer cellulose plate (TLC cellulose of analytical, Merck KGaA, Darmstadt, Germany) and developed with a solvent of $t$-butanol: formic acid: water $=4: 1: 1.5$. TLC plate was sprayed by a mixture of triphenyltetrazolum chloride (TTC) and $\mathrm{KOH}$. Sugar acids having intramolecular ketone are stained as a deep pink spot with TTC. F and 5KF mean the standard D-fructose and 5-keto-D-fructose, respectively.

molecule of D-fructose and two in 5KF, TTC reacted stronger with $5 \mathrm{KF}$ than $\mathrm{D}$-fructose. When $\mathrm{D}$-fructose formation during cultivation was assayed enzymatically, D-fructose accumulated as high as $82 \%$ to D-mannitol initially added, though D-fructose looked small from TLC chromatography. $5 \mathrm{KF}$ accumulated in the culture medium was finally measured to be $65 \%$ to the amount of D-mannitol initially added as shown in Figure 1.

The feature of D-mannitol utilization by $G$. frateurii CHM 43 was different from that of G. suboxydans IFO 12528 (renamed as G. oxydans NBRC 12528) which showed almost $100 \% \mathrm{D}$-fructose accumulation due to the absence of $\mathrm{FDH}$, as shown previously [14].
D-Mannitol was measured by NADP-dependent D-mannitol dehydrogenase (NADP-MLDH) from G. oxydans NBRC 12528 [15]. D-Fructose was measured by two ways with the membrane-bound FDH from G. japonicus NBRC 3260 [6] and NAD-dependent D-mannitol dehydrogenase from G. oxydans NBRC 12528 [15]. 5KF was measured by NADPH-dependent $5 \mathrm{KF}$ reductase (KFR) which can be prepared from one of the following strains: G. japonicus NBRC 3260, G. frateurii CHM 43, or G. oxydans NBRC 3257 [16].

$5 \mathrm{KF}$ production from D-mannitol was examined by resting cells of $G$. frateurii CHM 43 (Table 1), where $5 \mathrm{KF}$ was rapidly produced via $\mathrm{D}$-fructose. No 
Table 1. 5-Keto-D-fructose (5KF) production from D-mannitol with resting cells of $G$. frateurii CHM 43.

\begin{tabular}{lccc}
\hline $\begin{array}{l}\text { Incubation } \\
(\mathrm{h})\end{array}$ & $\begin{array}{c}\mathrm{D}-\text { Mannitol }^{a} \\
(\mathrm{~g} / \mathrm{L})\end{array}$ & $\begin{array}{c}\mathrm{D}^{2}-\text { Fructose }^{a} \\
(\mathrm{~g} / \mathrm{L})\end{array}$ & $\begin{array}{c}5 \mathrm{KF}^{a} \\
(\mathrm{~g} / \mathrm{L})\end{array}$ \\
\hline 0 & 50.0 & 0 & 0 \\
3 & 27.4 & 38.8 & 11.2 \\
6 & tr. $^{b}$ & 10.5 & 26.7 \\
12 & tr. & tr. & 50.0 \\
\hline
\end{tabular}

${ }^{a}$ The resting cells were prepared with the cells of $G$. frateurii $\mathrm{CHM} 43$ after cultivation for $36 \mathrm{~h}$ on D-mannitol with the same composition as in Figure 1. The cells were collected and washed two times with $5 \mathrm{mM}$ acetate buffer, $\mathrm{pH}$ 5.0. The cell suspension of $240 \mathrm{mg}$ wet wt./mL was used. The reaction mixture $(1 \mathrm{~mL})$ containing $0.4 \mathrm{~mL}$ of cells $(96 \mathrm{mg}$ wet cells), $50 \mathrm{mg}$ of D-mannitol, and $0.5 \mathrm{~mL}$ of $0.2 \mathrm{M}$ acetate buffer, $\mathrm{pH} 5.0$, was incubated. The reaction was shaken at $150 \mathrm{rpm}$ at $25^{\circ} \mathrm{C}$ and the reaction was terminated periodically as indicated by the addition of trichloroacetic acid to $2 \%$. After the reaction mixture was spun down by a table top centrifuge, an aliquot of the supernatant was used. D-Mannitol, D-fructose, and 5KF were measured under the same methods as indicated in Figure 1.

$b_{\text {tr., }}$ trace amount less than $0.01 \mathrm{~g} / \mathrm{L}$.

D-mannitol and D-fructose was detected by the enzymatic method described above at the end of the reaction, when the incubation was carried out in acetate buffer, $\mathrm{pH} 5.0$, at $25^{\circ} \mathrm{C}$ for $12 \mathrm{~h}$. Thus, the resting cells of $G$. frateurii CHM 43 were shown to be a potent catalyst for $5 \mathrm{KF}$ production from D-mannitol with almost $100 \%$ yield within a short period. D-Fructose behaved as a metabolic intermediate with a short lifetime. The reaction conditions employed seemed to be not far from the optimum condition, though it was not examined exactly.

\section{Acknowledgments}

Correct reading of manuscript was acknowledged to Mr. Roni Miah.

\section{Disclosure statement}

No potential conflict of interest was reported by the authors.

\section{Funding}

A part of this work was financially supported by the Yamaguchi University Fund (2019) from the Yamaguchi University Foundation.

\section{Author contribution}

OA, TMN, NK, KM, YA, and TY designed the study. OA and TMN performed the experiments. OA wrote the manuscript in consultation with RAH, NK, KM, and TY.

\section{References}

[1] Terada O, Tomizawa K, Suzuki S, et al. Formation of 5-dehydrofructose by members of Acetobacter. Bull Agric Chem Soc Jpn. 1960;24:535-536. .

[2] Terada O, Tomizawa K, Kinoshita S. Formation of 5-dehydrofructose by members of Acetobacter species. Part I. Formation of a new strong reducing substance from fructose and its discrimination from glucosone. Bull Agric Chem Soc Jpn. 1961;35:127-130.

[3] Terada O, Tomizawa K, Suzuki S, et al. Formation of 5-dehydrofructose by members of Acetobacter species. Part II. Studies on the fermentation, purification and properties of crystal. Bull Agric Chem Soc Jpn. 1961;35:131-134.

[4] Terada O, Suzuki S, Kinoshita S. Formation of 5-dehydrofructose by members of Acetobacter species. Part III. Characterization of the unknown substance. Bull Agric Chem Soc Jpn. 1961;36:178-182.

[5] Mowshowitz S, Avigad G, Englard S. 5-Keto$\mathrm{D}$-fructose: formation and utilization in the course of D-fructose assimilation by Gluconobacter cerinus. J Biol Chem. 1974;118:1051-1058.

[6] Ameyama M, Shinagawa E, Matsushita K, et al. D-Fructose dehydrogenase of Gluconobacter industrius. Purification, characterization and application to enzymatic microdetermination of $\mathrm{D}$-fructose. J Bacteriol. 1981;145:814-823.

[7] Kawai S, Goda-Tsutsumi M, Yakushi T, et al. Heterologous overexpression and characterization of a flavoprotein-cytochrome $c$ complex fructose dehydrogenase of Gluconobacter japonicus NBRC3260. Appl Environ Microbiol. 2013;79:1654-1660.

[8] Siemen A, Kosciow K, Schweiger P, et al. Production of 5-keto-D-fructose from fructose or sucrose using genetically modified Gluconobacter oxydans strains. Appl Microbiol Biotechnol. 2018;102:1699-1710.

[9] Herweg E, Schöpping M, Rohr K, et al. Production of the potential sweetener 5-ketofructose from fructose in fed-batch cultivation with Gluconobacter oxydans. Bioresour Technol. 2018;259:164-172.

[10] Hoffmann JJ, Hövels M, Kosciow K, et al. Synthesis of the alternative sweetener 5-ketofructose from sucrose by fructose dehydrogenase and invertase producing Gluconobacter strains. J Biotechnol. 2020;307: 164-174.

[11] Battling S, Wohlers K, Igwe C, et al. Novel plasmid-free Gluconobacter oxydans strains for production of the natural sweetener 5-ketofructose. Microb Cell Factor. 2020;19:article number 54. .

[12] Blasi M, Barbe JC, Dubourdieu D, et al. New method for reducing the binding power of sweet white wines. J Agr Food Chem. 2008;56:8470-8474.

[13] Wyrobnik DH, Wyrobnik IH. Agent for use in the case of disorders of blood sugar metabolism, including diabetes, Pro Natura Gesellschaft fur gensunde Emahrrung mbH (Frankfurt am Masin), DE, EP 1951293 B1.

[14] Moonmangmee D, Adachi O, Ano Y, et al. Isolation and characterization of thermotolerant Gluconobacter strains catalyzing oxidative fermentation at higher temperatures. Biosci Biotechnol Biochem. 2000;64:2306-2315.

[15] Adachi O, Toyama H, Matsushita K. Crystalline NADP-dependent D-mannitol dehydrogenase from Gluconobacter suboxydans. Biosci Biochem Biotechnol. 1999;63:402-407. .

[16] Ameyama M, Matsushita K, Shinagawa E, et al. 5-Keto-D-fructose reductase of Gluconobacter industrius. Purification, crystallization and properties. Agric Biol Chem. 1981;45:863-869. 